\title{
PŘEVEDENÍ NA JINOU PRÁCI OPTIKOU NEJNOVĚJŠÍ KONCEPČNÍ NOVELY ZÁKONÍKU PRÁCE*
}

\author{
LUCIE řEHOŘOVÁ**
}

\begin{abstract}
Transfer to Alternative Work in a View of the Latest Conceptual Labour Code Amendment

The article deals with the concept of the transfer of an employee to alternative work. The first part of the article analyses the current regulation of the transfer to alternative work while the second part of the article focuses on the latest amendment to the Labour Code which should affect inter alia also this institute. The author of this article assesses the practical impact of the amendment on labour relations while taking into account the attitude of the social partners on the proposed regulation. Particular attention is paid to the obligation of an employer to transfer of an employee to alternative work.
\end{abstract}

Keywords: transfer to alternative work; obligation of an employer; autonomy of will; labour relations.

Klíčová slova: převedení na jinou práci; povinnost zaměstnavatele; autonomie vưle; pracovněprávní vztahy.

DOI: $10.14712 / 23366478.2016 .52$

\section{SLOVO ÚVODEM}

Změny definují společenství lidí již od prvopočátku; reflektují objektivní sociálně-ekonomickou dynamiku i subjektivní vývoj jednotlivce; jsou př́činou nezbytného pokroku a vývoje společnosti, sociální skupiny osob, rodiny, partnerských vztahů i člověka jako takového. Vzhledem k povaze výkonu závislé práce, zejména k osobnímu vztahu zaměstnavatele a zaměstnance nemohou být ani vztahy pracovněprávní od okolního světa izolovány a musejí reflektovat nastalé změny, které mohou částečně modifikovat některé jeho prvky. Nejdůležitějším úkolem zákonodárce $\mathrm{v}$ této oblasti je reagovat na změny úpravou vhodných podmínek, které umožní jejich realizaci a přitom nevyvolají ukončení pracovněprávního vztahu.

* Př́spěvek zohledňuje právní stav ke dni 31. 7. 2016.

** Mgr. Lucie Řehořová působí na Katedře pracovního práva a práva sociálního zabezpečení Právnické fakulty Univerzity Karlovy jako interní doktorandka a zároveň jako advokátní koncipientka v advokátní kanceláři v Praze. 
Změna pracovněprávního vztahu bývá definována jako změna základních podmínek či prvků v právním vztahu zaměstnavatele a zaměstnance, $v$ němž je práce konána. Pojmem ,právní vztah zaměstnavatele a zaměstnance“ se rozumí základní pracovněprávní vztahy, jakými jsou pracovní poměr a právní vztahy založené dohodami o pracích konaných mimo pracovní poměr, stejně jako právní vztahy odvozené či související. ${ }^{1}$

Přestože se podmínky výkonu práce v rámci vztahů založených dohodami o pracích konaných mimo pracovní poměr mohou rovněž měnit, lze tak činit pouze po vzájemné dohodě smluvních stran; předkládaný př́spěvek bude proto zaměřen pouze na změny nastalé $\mathrm{v}$ pracovním poměru, konkrétně na převedení zaměstnance na jinou práci, které je vedle změny místa výkonu práce jednou z nejčastějších změn obsahu pracovního poměru. ${ }^{2}$ Pozornost bude zaměřena především na práva a povinnosti související s převedením zaměstnance, která nejsou výsledkem volního uvážení smluvních stran, nýbrž která odvisí od zákonodárcem kogentně stanovených zákonných příkazů.

Pracovní poměr jakožto právní vztah založený převážně pracovní smlouvou, tj. dvoustranným právním jednáním, by měl být z povahy věci a při současném respektování autonomie vůle jeho účastníků oboustranně flexibilní, to znamená, že jakákoli změna jeho prvku by měla být výsledkem jednání a potvrzením konsensu obou smluvních stran tak, aby mohl být zachován a nebylo nutné jeho předčasné ukončení.

Současná právní úprava této myšlence neodpovídá, když ust. § 41 zákona č. 262/2006 Sb., zákoník práce (dále jen „zákoník práce“), představuje typicky jednostranně flexibilní právní normu, na základě které je zaměstnavateli umožněno v určitých prrípadech převést zaměstnance na jinou práci i bez jeho souhlasu.

Ačkoli byla stávající koncepce institutu převedení na jinou práci soustavně z řad některých autorů ${ }^{3}$ opakovaně kritizována právě pro rozpor $\mathrm{s}$ autonomií vưle stran a smluvní povahou pracovního poměru vůbec, nedoznalo ustanovení § 41 zákoníku práce, vyjma marginálních legislativně-technických novelizací, od doby přijetí soudobého zákoníku práce žádných výraznějších změn.

$\mathrm{S}$ připomínkou „nic netrvá věčně“ nicméně pokročíme dále $\mathrm{v}$ textu, který v následujících kapitolách analyzuje nejnovější návrh novely zákoníku práce, který v letošním roce vyšel z pera Ministerstva práce a sociálních věcí, a který cílí mimo jiné rovněž na změnu ustanovení $§ 41$ zákoníku práce a koncepce převedení zaměstnance na jinou práci jako takovou.

Příspěvek má za cíl analyzovat návrh novely zákoníku práce v části zabývající se převedením na jinou práci, resp. řečeno navrhovanou terminologií „výkonem jiné práce" a posoudit praktické dopady nové koncepce na pracovněprávní vztahy za současného zohlednění postoje sociálních partnerů k navrhované úpravě.

$1 \mathrm{~K}$ tomu více HŮRKA in BĚLINA, Miroslav - PICHRT, Jan - ŠTANGOVÁ, Věra a kol.: Pracovni právo. 6. doplněné a podstatně přepracované vydání. Praha: C. H. Beck, 2014, s. 180.

$2 \mathrm{~S}$ ohledem na specifika pracovněprávních vztahů je změna jejich jednotlivých prvků omezena. Změna u objektu pracovního poměru z logiky věci př́ípustná není, obdobně tak změna na straně zaměstnance. Nejčastěji měněným prvkem pracovního poměru je bezesporu jeho obsah, tj. konkrétní práva a povinnosti, která z tohoto vztahu vyplývají.

3 Srov. BEZOUŠKA, Petr - HƯRKA, Petr: Náměty ke koncepční novele zákoníku práce. Právní rozhledy, 2009 , č. 10 , s. 352 a násl. 


\section{STÁVAJÍCÍ PŘEVEDENÍ NA JINOU PRÁCI}

Hovoříme-li o změnách pracovního poměru, je na místě zmínit obecné ustanovení § 40 zákoníku práce, dle kterého je možné obsah pracovního poměru změnit jen tehdy, dohodnou-li se na jeho změně zaměstnavatel a zaměstnanec. Konat práce jiného druhu než byly sjednány v pracovní smlouvě je zaměstnanec povinen jen v př́ipadech uvedených $\mathrm{v}$ zákoně.

Současná právní regulace však navzdory obecné zásadě souhlasu obou smluvních stran upravuje převedení zaměstnance na jinou práci jako jednostranné oprávnění zaměstnavatele ( $v$ určitých př́padech dokonce jeho zákonnou povinnost), které lze provést $\mathrm{i}$ bez souhlasu převáděného zaměstnance. Převedení zaměstnance na jinou práci tak není závislé na vưli zaměstnance a vyplývá ze vztahů nadřízenosti zaměstnavatele a podř́izenosti zaměstnance. Zaměstnavatel nadto může zaměstnance ve smyslu ust. $\S 41$ odst. 3 zákoníku práce převést i mimo rámec sjednaného druhu práce v pracovní smlouvě, a to i kdyby s tím zaměstnanec nesouhlasil, vždy však musí zaměstnavatel při takovém převedení přihlížet $\mathrm{k}$ tomu, aby taková práce byla pro zaměstnance vhodná vzhledem k jeho zdravotnímu stavu, schopnostem a pokud možno i kvalifikaci (srov. ust. $§ 41$ odst. 1,3 a 6 zákoníku práce). ${ }^{4}$

Konkrétní př́ípady, za kterých je zaměstnavatel povinen převést zaměstnance na jinou práci, stanoví zákoník práce taxativně v ust. $§ 41$ odst. 1 . Toto ustanovení je důsledkem především ochranné funkce pracovního práva, kdy chrání zdraví zaměstnance, jiných zaměstnanců, třetích osob a celospolečenské zájmy. Povinnost zaměstnavatele převést zaměstnance na jinou práci je vždy spojena s vydáním lékařského posudku ${ }^{5}$ nebo rozhodnutí soudu, správního orgánu či orgánu územně samosprávného celku. ${ }^{6}$

Jedná se o následující důvody převedení:

a) pozbyl-li zaměstnanec vzhledem ke svému zdravotnímu stavu dlouhodobě způsobi-

lost konat dále dosavadní práci; podmínkou převedení je vždy lékařský posudek;

b) nesmí-li zaměstnanec dále konat dosavadní práci pro pracovní úraz, nemoc z povolání nebo pro ohrožení touto nemocí; podmínkou převedení je zde také lékařský posudek;

c) dosáhl-li na pracovišti nejvyšší př́ípustné expozice; podmínkou převedení na jinou práci je zde rozhodnutí prríslušného orgánu ochrany veřejného zdraví;

4 Nejvyšší soud učinil dne 19.6. 1975 rozhodnutí publikované pod č. 51/1975, v němž dovodil, že takovou prací, která má pokud možno odpovídat i kvalifikaci zaměstnance, je třeba rozumět př̌edevším práci odpovídající jeho kvalifikaci, teprve potom (není-li místo odpovídající kvalifikaci zaměstnance volné) práci, která odpovídá pokud možno nejvíce kvalifikaci zaměstnance, a posléze (není-li volné ani pracovní místo odpovídající co nejvíce kvalifikaci zaměstnance) práci, pro kterou se zvláštní kvalifikace nevyžaduje.

5 Lékařský posudek vydává poskytovatel pracovnělékařských služeb, který v něm musí jednoznačně stanovit důvod převedení na jinou práci. Lékařský posudek nabývá právních účinků dnem jeho prokazatelného předání posuzované osobě (zaměstnanci) a tomu, kdo o posouzení zdravotní způsobilosti posuzované osoby za účelem vydání posudku požádal (zaměstnavateli). Závěr lékařského posudku je možno přezkoumat do 10 dnů od jeho prokazatelného předání, $\mathrm{k}$ přezkoumání je oprávněn př́islušný správní orgán.

6 S výjimkou povinnosti zaměstnavatele převést těhotnou zaměstnankyni, zaměstnankyni, která kojí nebo zaměstnankyni matku do konce devátého měsíce po porodu, která pracuje v noci, na základě žádosti této zaměstnankyně. 
d) koná-li těhotná zaměstnankyně, zaměstnankyně, která kojí, nebo zaměstnankyně - matka do konce devátého měsíce po porodu práci, kterou nesmějí být tyto zaměstnankyně zaměstnávány nebo která podle lékařského posudku7 ohrožuje její těhotenství nebo mateřství; podmínka lékařského posudku je vyžadována pouze pro posouzení, zda konané práce ohrožují těhotenství či mateřství zaměstnankyně ze zdravotních důvodů;

e) jestliže to je nutné podle lékařského posudku vydaného poskytovatelem pracovnělékařských služeb nebo rozhodnutí př́islušného orgánu ochrany veřejného zdraví v zájmu ochrany zdraví jiných fyzických osob před infekčním onemocněním;

f) jestliže je toho třeba podle pravomocného rozhodnutí soudu nebo správního úřadu, jiného státního orgánu nebo orgánu územního samosprávného celku; typicky rozhodnutí o zákazu výkonu určité práce;

g) je-li zaměstnanec pracující v noci na základě lékařského posudku vydaného poskytovatelem pracovnělékařských služeb uznán nezpůsobilým pro noční práci;

h) požádá-li o to těhotná zaměstnankyně, zaměstnankyně, která kojí, nebo zaměstnankyně-matka do konce devátého měsíce po porodu, která pracuje v noci - pouze $\mathrm{v}$ tomto prípadě dává zaměstnanec s převedením de facto souhlas tím, že ho sám iniciuje svojí žádostí. ${ }^{8}$

Ustanovení § 41 odst. 2 a 4 zákoníku práce definuje př́ípady, kdy není dána zákonná povinnost, nýbrž záleží na uvážení zaměstnavatele, zda zaměstnance na jinou práci převede, či zda jej na stávající pracovní pozici zachová. Toto oprávnění zaměstnavatele převést zaměstnance přiznává zákoník práce $\mathrm{v}$ následujících př́ípadech:

a) dal-li zaměstnavatel zaměstnanci výpověd' $z$ důvodů uvedených $v$ ust. § 52 písm. f) a g), tj. pro nesplňování požadavků či předpokladů stanovených pro výkon sjednané práce nebo pro porušování právních předpisů vztahujících se $\mathrm{k}$ vykonávané práci;

b) bylo-li proti zaměstnanci zahájeno trestní řizení pro podezření z úmyslné trestné činnosti spáchané př̀i plnění pracovních úkolů nebo v přímé souvislosti s ním ke škodě na majetku zaměstnavatele, a to na dobu do pravomocného skončení trestního řízení;

c) pozbyl-li zaměstnanec dočasně předpoklady stanovené zvláštními právními předpisy pro výkon sjednané práce, nejdéle na 30 pracovních dnů v roce;

d) je-li to třeba k odvrácení mimořádné události, živelní události nebo jiné hrozící nehody nebo k zmírnění jejich bezprostředních následků, a to na nezbytně nutnou dobu.

S výjimkou převedení zaměstnance na jinou práci k odvrácení mimořádné události, živelní události nebo jiné hrozící škody, je zaměstnavatel i zde povinen přihližžet k tomu, aby práce, na kterou zaměstnance převádí, byla vhodná s ohledem na jeho zdravotní stav, schopnosti a kvalifikaci.

7 Lékařský posudek zde není vyžadován od poskytovatele pracovnělékařských služeb, ale může se jednat o lékařský posudek jakýkoli, který posuzuje, zda zaměstnankyni vykonávaná práce ohrožuje na těhotenství či mateřství ze zdravotních důvodů.

8 K tomu více BĚLINA, Miroslav - DRÁPAL, Ljubomír - PICHRT, Jan a kol.: Zákoník práce. Komentár. 2. vyd. Praha: C. H. Beck, 2015, s. 252 a násl. 


\section{NAVRHOVANÝ VÝKON JINÉ PRÁCE}

Dle Ministerstva práce a sociálních věcí z pozice předkladatele nese poslední navrhovaná novela opět př́izvisko „koncepční“, 9 prričemž jejím cílem je ,prohloubit flexibilitu základnich pracovněprávnich vztahů za současného posílení ochrany postavení zaměstnance $v$ těchto právních vztazich ${ }^{.}{ }^{10}$ Citovaný cíl není více než vyjádření obecné snahy zákonodárce o flexicuritu v pracovněprávních vztazích, jakými prostředky však má být uvedeného cíle konkrétně dosaženo v rámci institutu převedení zaměstnance na jinou práci?

Návrh novely mění v prvé řadě terminologii zákona, kdy podle stávající úpravy jsou $\mathrm{v}$ souvislosti se změnami obsahu pracovního poměru (pokud jde o změnu sjednaného druhu práce či místa výkonu práce) používány termíny „převedení“ a „přeložení“ zaměstnance, které evokují jednostrannou dispozici zaměstnavatele vůči zaměstnanci, ačkoli tuto dispozici lze využít pouze $\mathrm{v}$ př́ípadě převedení zaměstnance na jinou práci (nikoli při přeložení zaměstnance do jiného místa), a to pouze $\mathrm{v}$ př́ípadech zákonem stanovených. Novela má např́ště uzpůsobit terminologii v této oblasti smluvnímu charakteru pracovního poměru, kdy současné „převedení“ bude nově „,výkonem jiné práce“ a „přeložení“ bude nahrazeno pojmem „dočasná změna místa výkonu práce“.

Koncepčně je navrhována změna institutu převedení na jinou práci způsobem, který naváže výkon jiné práce vždy na souhlas dotčeného zaměstnance se změnou podmínek v pracovní smlouvě. Dosavadní zákonná povinnost zaměstnavatele převést má být nahrazena povinností nabídkovou. Akceptace nabídky jiné vhodné práce zaměstnancem by byla založena na smluvním ujednání mezi oběma stranami pracovního poměru ve formě dohody o změně pracovní smlouvy v souladu s principem zakotveným v ust. § 40 odst. 1 zákoníku práce. Jedinou výjimkou, kdy by zaměstnavateli zůstalo oprávnění jednostranně převést zaměstnance na jinou práci i bez jeho souhlasu, je případ mimořádné události, živelní události nebo jiné hrozící nehody, když tyto okolnosti přesahují zájem obou stran pracovněprávního vztahu.

Novela zachovává skutkové podstaty stávajícího ust. § 41 odst. 1 zákoníku práce a navrhuje do toho ustanovení přidat písm. h), které má nově upravovat povinnost zaměstnavatele přidělit zaměstnanci jinou vhodnou práci v prŕpadě, kdy zaměstnanec dočasně pozbyl předpoklady stanovené zvláštními právními předpisy pro výkon sjednané práce. Podle současné úpravy zakládá dočasné pozbytí předpokladů pro výkon sjednané práce pouze možnost zaměstnavatele převést zaměstnance na jinou práci, v novelizovaném znění bude přidělení jiné práce zaměstnanci přikázáno.

Novela vedle výše uvedeného jednoznačně zakotvuje definici vhodné práce, kterou se rozumí práce, která je pro zaměstnance vhodná vzhledem k jeho zdravotnímu stavu, schopnostem a pokud možno i kvalifikaci, uvedené lze považovat pouze za přehlednější formu, obsahově v tomto směru ke změně nedochází.

S novým pojetím nabídkové povinnosti přidělení jiné vhodné práce souvisí na tuto povinnost navázaný systém překážek v práci, a to jak na straně zaměstnavatele, tak

9 Jako koncepční byly $\mathrm{v}$ posledních letech prezentovány novely zákoníku práce provedené zákonem č. 365/2011 Sb., s účinností od 1. 1. 2012 a zákonem č. 205/2015 Sb., s účinností od 1. 10. 2015.

10 Shrnutí závěrečné zprávy RIA k návrhu novely zákoníku práce dostupné na www.mpsv.cz. 
na straně zaměstnance, pokud $\mathrm{k}$ přidělení a $\mathrm{k}$ výkonu jiné práce nedojde $\mathrm{z}$ důvodů na té které smluvní straně pracovněprávního vztahu. Novelizované znění zákona výslovně stanoví, že pokud zaměstnanec navrženou jinou vhodnou práci odmítne, jedná se o překážku v práci na straně zaměstnance, při níž zaměstnanci zcela logicky náhrada mzdy nebo platu nepř́íluší. Pokud zaměstnavatel nemá pro zaměstnance jinou vhodnou práci, jedná se o překážku v práci na straně zaměstnavatele a zaměstnanci po dobu jejího trvání přísluší náhrada mzdy nebo platu ve výši průměrného výdělku. Uvedené platí obdobně, pokud zaměstnavatel nenavrhne zaměstnanci zařazení na jinou vhodnou práci, ačkoli pro něj takovou práci má.

Až posléze bylo ustanovení návrhu novely věnované překážkám v práci doplněno o dovětek, dle kterého pokud zaměstnanec svým zaviněným jednáním způsobil, že dosavadní práci nesmí vykonávat z důvodů uvedených v ust. § 41 odst. 1 písm. e) a h) zákoníku práce ${ }^{11}$ a zaměstnavatel pro něj jinou vhodnou práci nemá, nepřísluší mu náhrada mzdy nebo platu. Bez uvedeného ustanovení by se jednalo o vychýlení povinností zaměstnavatele vůči zaměstnanci ad absurdum, když uvážíme typický prrípad: kdy zaměstnanec - řidič přijde o řidičské oprávnění v důsledku jízdy pod vlivem alkoholu, čímž naplní podmínku nesplnění předpokladů pro výkon sjednané práce, přičemž by se podle původně navrhované úpravy dostal do režimu překážek v práci na straně zaměstnance, $v$ rámci které by mu zaměstnavatel byl povinen vyplácet náhradu mzdy nebo platu ve výši průměrného výdělku, pokud pro něj nemá náhradní vhodnou práci odpovídající jeho schopnostem a kvalifikaci (což v prŕípadě profesionálních řidičů zaměstnavatel většinou nemá).

Pozbytí předpokladů stanovených zvláštními právními předpisy jako navrhovaná nová prríčina nabídkové povinnosti zaměstnavatele vyvolává pochybnosti rovněž ve vztahu k možné relativizaci výpovědního důvodu uvedeného v ust. § 52 písm. f) zákoníku práce. Podle současné právní úpravy má zaměstnavatel možnost převést zaměstnance $\mathrm{v}$ tomto případě na jinou práci, zároveň s tím má také možnost rozvázat $\mathrm{z}$ tohoto důvodu pracovní poměr. Bude-li současné oprávnění zaměstnavatele převedeno na povinnost přidělit zaměstnanci jinou vhodnou práci, nezpochybňuje se tím důvod k ukončení pracovního poměru s tímto zaměstnancem?

Cílem navrhované právní úpravy je dle Ministerstva práce a sociálních věcí výrazné omezení výlučného dispozičního oprávnění zaměstnavatele k jednostrannému převedení zaměstnance na jinou práci mimo rámec pracovní smlouvy nezávisle na vůli zaměstnance při současném zachování povinnosti zaměstnavatele zabezpečit zaměstnanci jinou vhodnou práci, nemůže-li dosavadní z důvodů v zákoně uvedených vykonávat. ${ }^{12}$

Pouze okrajově se na tomto místě sluší upozornit, že v případě státních zaměstnanců a jejich služebních poměrů regulovaných zákonem č. 234/2014 Sb., o státní službě, je jednostranné převedení na jiné služební místo ve smyslu ust. § 61 zákona o státní službě možné, přitom ačkoli se do služebního poměru zaměstnanec přijímá rozhodnutím slu-

11 V př́ípadě rozhodnutí soudu, správního úřadu či jiného státního orgánu a orgánu územně samosprávného celku a pozbyl-li zaměstnanec dočasně předpoklady pro výkon sjednané práce.

12 Takto popisuje předkladatel cílový stav v Závěrečné zprávě RIA k návrhu novely zákoníku práce dostupné na www.mpsv.cz. 
žebního orgánu, základní principy výkonu závislé činnosti platí bezesporu i v př́ípadech státního zaměstnance.

\section{POHLED SOCIÁLNÍCH PARTNERŮ}

Navrhovaná novela Ministerstva práce a sociálních věcí vyvolala u odborné veřejnosti rozsáhlé diskuze, nejsilnější hlasy se však ozývají od sociálních partnerů, zejména z řad zástupců zaměstnavatelů, jejichž nejzásadnější připomínky směřují právě ke způsobu novelizace ustanovení upravující převedení zaměstnance na jinou práci.

Svaz průmyslu a dopravy České republiky zaujal v této souvislosti stanovisko, dle kterého převedení $\mathrm{i}$ bez souhlasu zaměstnance není $\mathrm{v}$ rozporu se smluvními principy pracovněprávních vztahů. Přidělení práce $\mathrm{v}$ rámci sjednaného druhu práce je oprávněním zaměstnavatele a záleží pouze na něm, kdy a jak takového práva využije. Pokud jde o převedení na jinou práci mimo sjednaný rámec pracovní smlouvy, je navrhované úpravě vytýkáno nerespektování skutečnosti, že mnoho malých a středních zaměstnavatelů není schopno vytvářet vhodná pracovní místa pro zaměstnance, kteří se stanou nezpůsobilými vykonávat dosavadní práci z důvodů nesouvisejících s prací u zaměstnavatele. Stran zdravotní nezpůsobilosti zaměstnance nadále vykonávat sjednaný druh práce za dobu trvání pracovního poměru Svaz průmyslu a dopravy České republiky připomněl, že obdobná závažná změna okolností, která nastala za trvání závazku, by byla ve smyslu ust. § 2006 zákona č. 89/2012 Sb., občanský zákoník, u jiných soukromoprávních závazků př́činou jejich zániku ex lege pro následnou nemožnost plnění. ${ }^{13}$

Ještě skeptičtější je k navrhovanému znění novely zákoníku práce Konfederace zaměstnavatelských a podnikatelských svazů České republiky (dále jen „Konfederace ZPS“). Konfederace ZPS vnímá navrhovanou úpravu jako nelogickou a nespravedlivou.

Změna podle ní vede $\mathrm{k}$ neodůvodnitelné nerovnováze a narušení smyslu pracovněprávního vztahu. Na jeho počátku, př́íp. v jeho průběhu, se strany dohodnou, co a za jakých podmínek bude zaměstnanec vykonávat, nicméně v okamžiku, kdy nemůže zaměstnanec nadále sjednanou práci konat $\mathrm{z}$ př́ícin na jeho straně, není podle Konfederace ZPS možné požadovat po zaměstnavateli, aby nesl tíži ztráty způsobilosti či předpokladů, která vznikla na straně zaměstnance a kterou nezavinil. Zaměstnavatel v uvedených př́padech nijak nezavinil ani neovlivnil pozbytí způsobilosti zaměstnance konat dále dosavadní práci, která byla sjednána v pracovní smlouvě. Menší a střední zaměstnavatelé nejenže nemají ve většině př́ípadů žádnou vhodnou práci, ale nemají žádnou jinou práci. Zaměstnanec byl přijat na práci vymezenou v pracovní smlouvě a způsobilost ji vykonávat ztratil sám. Realita pracovního trhu je naopak taková, že zaměstnavatelé nevytváŕí a neudržují vhodná pracovní místa, aniž by je potřebovali. Nové pracovní místo je vytvořeno a obsazeno vždy v době, kdy je to nutné, a kdy to zaměstnavateli okolnosti umožňují. ${ }^{14}$

13 ČMKOS: Koncepční novela zákoníku práce a postoj sociálních partnerư. Praha: Sondy, s.r.o., 2016, s. 27.

14 ČMKOS: Koncepčni novela zákoniku práce a postoj sociálních partnerů. Praha: Sondy, s.r.o., 2016, s. 50 a násl. 
Obecně navrhují zástupci zaměstnavatelů zachovat vznik překážky v práci na straně zaměstnavatele a s ní spojenou povinnost k náhradě mzdy nebo platu ve výši průměrného výdělku pouze $v$ př́ípadě, kdy zaměstnavatel nenavrhne zaměstnanci zařazení na jinou vhodnou práci, ačkoli takovou vhodnou práci pro něho má.

\section{ZÁVĚREM}

Předkládaný př́spěvek měl za cíl poukázat na základní aspekty jednostranného převedení zaměstnance na jinou práci z pohledu současné právní úpravy, jakož i z pohledu navrhované koncepční novely zákoníku práce. Jak bylo nastíněno v poslední části textu, stojí proti navrhované novele silná opozice sociálních partnerů, zejména $\mathrm{z}$ řad zaměstnavatelů. Jejich argumenty týkající se především pojetí překážek na straně zaměstnance a povinnosti zaměstnavatele poskytovat zaměstnanci náhradu mzdy nebo platu ve výši průměrného výdělku jistě nelze přehlížet.

Velmi lehce se může středně velký zaměstnavatel, jehož pracovní kolektiv sestává převážně z žen ve věku 20-40 let, dostat do situace, kdy mu nezanedbatelná část zaměstnankyň otěhotní a budou uznány neschopné výkonu dosavadní práce (prrípadně samy požádají o převedení na jinou práci ve smyslu ust. § 41 odst. 1 písm. g) zákoníku práce). Nebude-li pro ně mít zaměstnavatel jinou vhodnou práci, dostává se automaticky do režimu překážek v práci na straně zaměstnavatele, ve kterém náleží v souladu s ust. § 208 zákoníku práce zaměstnancům náhrada mzdy ve výši průměrného výdělku. Náklady takového zaměstnavatele na odměny budou nadále čítat vedle nákladů na příslušné náhrady mzdy zaměstnankyním toho času v režimu překážek v práci rovněž náklady na řádné mzdy pro zastupující zaměstnance. Uvedené ve svém důsledku znamená, že bude zaměstnavatel na jedno pracovní místo vyplácet odměnu dvakrát. Pouze pro úplnost je třeba uzavřít, že tento systém může mít pro mnoho zaměstnavatelů likvidační následky.

Bez povšimnutí nicméně nemůže zůstat aspekt zaměstnance, kdy pokud by režim překážek v práci pro tyto př́ípady stanoven nebyl a zaměstnavatel by neměl povinnost vyplácet zaměstnanci náhradu mzdy nebo platu ve výši průměrného výdělku, mohl by se zaměstnanec, který byl shledán dočasně práce nezpưsobilý, ale u kterého nenastal režim dočasně práce neschopného zaměstnance, dostat do tíživé životní situace, kdy mu nebude náležet ani náhrada mzdy ani nemocenské. Typickým př́padem může být těhotná žena, které bylo lékařem diagnostikováno rizikové těhotenství, při kterém nevzniká nárok na dávky nemocenského pojištění. Lze po zaměstnavateli spravedlivě požadovat, aby ze svých prostředků dlouhodobě hradil náklady na jedno pracovní místo dvakrát? A lze přistoupit na eventualitu, ve které bude ponechána žena na rizikovém těhotenství zcela bez prostředků?

Závěrem lze říci, že snahu zákonodárce o přizpůsobení institutu převedení zaměstnance na jinou práci zásadám soukromoprávních individuálních závazkových vztahů lze vnímat veskrze pozitivně. Vždy je však třeba vzít na vědomí, zda režim překážek v práci, ve kterém náleží zaměstnanci náhrada mzdy ve výši průměrného výdělku, na jednu stranu teoreticky umožní zaměstnanci překlenout nastalou změnu v jeho pra- 
covněprávním vztahu, kdy mu po odpadnutí této překážky bude umožněno nastoupit na původní místo zpět; na druhou zde však stranu vyvstává obava, aby zaměstnavatel dodatečné náklady, které mu při převedení na jinou práci a překážky v práci s tím spojené vznikají, ustál, a aby se měl zaměstnanec po odpadnutí překážky vůbec kam vracet.

Teprve nejbližší měsíce ukáží, zda se navrhované novele v podobě analyzované $\mathrm{v}$ tomto článku podaří projít legislativním procesem a zda předkladatel ustojí připomínky ze strany sociálních partnerů a odborné veřejnosti.

Mgr. Lucie Řehořová

Právnická fakulta Univerzity Karlovy

lucie.rehorova@seznam.cz 